\title{
$\mathrm{ADHD}$ 의 한약물 치료에 대한 최신 임상연구 동향 -2007년부터 2012년까지 중국 논문을 중심으로-
}

\author{
유춘길, 조아람, 서주희, 정성식*, 이지수 ${ }^{\dagger}$, 성우용 $^{\dagger}$ \\ 국립중앙의료원 한방신경정신과, 한방내과*, 침구과 ${ }^{\dagger}$, \\ 부산대학교 한의학전문대학원 한방신경정신과교실 ${ }^{\ddagger}$
}

\section{The Current State of Clinical Studies for Herbal Medicine of Attention Deficit Hyperactivity Disorder (ADHD) -Focusing on Chinese Journals-}

\author{
Chun-Gil Ryu, A-Ram Cho, Joo-Hee Seo, Seong-Sik Jeong*, Ji-Su Lee ${ }^{\dagger}$, Woo-Yong Sung ${ }^{\ddagger}$ \\ Departments of Oriental Neuropsychiatry, "Oriental Internal Medicine, \\ ${ }^{+}$Oriental Acupucture and Moxibustion, National Medical Center, \\ ${ }^{*}$ Department of Oriental Neuropsychiatry, Pusan National University School of Korea Medicine
}

\begin{abstract}
Objectives :

The purpose of this study was to take around herbal medicine for Attention Deficit Hyperactivity Disorder in China.

Methods :

A journal search was performed using China National Knowledge Infrastructure (CNKI) from 2007 to 2012. Key words searched were 'ADHD'.
\end{abstract}

\section{Results :}

25 studies were selected. Case control studies showed that herbal medicine treatment reported better results than the western medicine treatment group. 12 case reports reported a significant improvement in herbal medicine treatment for patients with ADHD. Frequently used herbal materials were Rhizome of Polygalae Radix and Rhizome of Acori Gramineri Rhizoma (16 times), Root of Glycyrthiza uralensis Fisch (14 times), Root of Rehmanniae Radix et Rhizoma Preparata and Sclerotium of Poria cocos Wolf (12 times).

\section{Conclusions :}

There have been many studies regarding herbal medicine for Attention Deficit Hyperactivity Disorder in China, and these studies can be applied to the clinical practices in Korea.

Key Words:

ADHD, Herbal medicine, CNKI, Clinical study. 


\section{I. 서론}

주의력 결핍 과잉행동 장애(Attention Deficit Hyperactivity Disorder, ADHD)는 아동의 발달상 흔 히 볼 수 있는 행동장애의 하나로써, 주의집중력이 짧고 충동적인 행동, 그리고 과잉행동 성향 등을 주된 양상으로 한다 ${ }^{1)}$. 미국 아동에서는 아동의 약 3 7\%가 주의력 결핍-과잉행동 장애로 진단될 수 있다고 보고 있으며. 우리나라의 경우에도 2008년 서울시 환경보 건진흥원이 44 개교 초등학교 1학년과 4학년을 대상 으로 조사한 결과 유병율이 $3.8 \%$ 로 나타났고, 서울과 대전 지역을 대상으로 한 국내 역학조사 결과에서는 이보다 더 높은 $7.6 \%$ 의 유병율을 나타냈다 ${ }^{2)}$.

$\mathrm{ADHD}$ 아동의 서양의학적 치료 개입으로는 약물 치료와 비약물 치료로서의 부모교육 훈련, 인지행동 치료, 사회적 기술 훈련, 놀이치료를 비롯한 심리치료 등이 사용되며, 2004년부터 2008년까지 국내 ADHD 아동에 대한 치료를 분석한 결과 약물치료가 $67.3 \%$ 로 가장 많았다고 보고되었다. 이러한 약물치료는 즉 각적이고 단기적인 효과를 보이기는 하나 우리나라의 부모들이 아동에게 약물을 사용하는 것에 대한 부담 감이 있고, 아동에게 적절한 대처 행동을 습득시키는 데 한계가 있으며), 가장 흔히 사용되는 Methylphenidate (상품명-Ritalin)의 경우 맥박의 증가, 혈압의 증 가와 같은 심혈관계 부작용과 불면, 식욕감소, 두통, 위통, 낮 시간 졸림, 짜증, 불안 등의 부작용이 발생하 기 때문에 비약물 치료 등의 개입이 요구되어 왔단)

한의학의 고대 문헌 중에서 정확히 일치하는 병증 과 개념에 대한 논술은 없으나 임상 증상을 근거로 볼 때, “風”, “躁動”, “失聰”, “健忘” 등의 범주에 속한다 고 할 수 있으며, 소아는 神氣가 怯弱하여 잘 놀래고 화도 잘 내고, 기빼하기도 잘함으로, 섭생부족 등이 있을 때 이러한 증후가 쉽게 발생한다고 보고 있다도.

국내에서 한약물을 사용한 임상 연구로는 Byun ${ }^{6}$, $\mathrm{Kim}^{7)}$ 등 소수의 증례보고만이 발표되었고, 문헌적 고찰 역시 2006년 이전 ADHD 치료법에 대해서만
포괄적으로 이루어져 왔다 ${ }^{8-10)}$. 이에 본 연구에서는 $\mathrm{ADHD}$ 연구가 보다 더 활발히 진행되고 있는 중국에 서 2007년 이후 발표된 임상 논문의 고찰을 통해 $\mathrm{ADHD}$ 의 한약물 치료에 대한 최신 동향을 파악하여 임상적 접근에 도움을 주고자 한다.

\section{II. 연구방법}

\section{1. 논문의 검색}

인터넷 중국 논문 검색사이트인 CNKI (China National Knowledge Infrastructure; 中國知識基礎施 設工程)에서 제공하는 CAJ (China Academic Journals; 中国学术期刊全文数据)를 이용하여 2007년에서 2012년까지의 $\mathrm{ADHD}$ 관련 논문을 검색하였다. 검색범 위는 醫藥衛生(Medicine/Hygiene)의 “中医学”, “中药 学”, “中西医结合”으로 검색어 “注意力缺陷多动障碍”, “小儿多动症”, “ADHD”, “兒童多動症”을 이용하여 검 색하였다. 논문의 검색은 2013년 1월에 시행하였다.

\section{2. 논문의 선별}

논문의 선정기준은 사람을 대상으로 한 연구이면 서 대상자는 $\mathrm{ADHD}$ 환자이고, 복합장애일 경우 주진 단이 $\mathrm{ADHD}$ 인 경우, 복합치료를 한 경우 주 치료 방 법이 한약물인 경우로 하였다. 동물 대상 연구, $\mathrm{ADHD}$ 가 주진단이 아닌 경우, 한약물 치료가 주치료 방법이 아닌 경우, 종설 논문인 경우는 제외하였다. 본 연구의 선정기준을 바탕으로 2 명의 연구자가 의견 합의를 이룬 논문을 포함시켰다. 또한 비교임상연구 에 대해서는 Jadad Quality Assessment Scale을 이용 하여 논문의 질을 평가하였다 ${ }^{11)}$. 


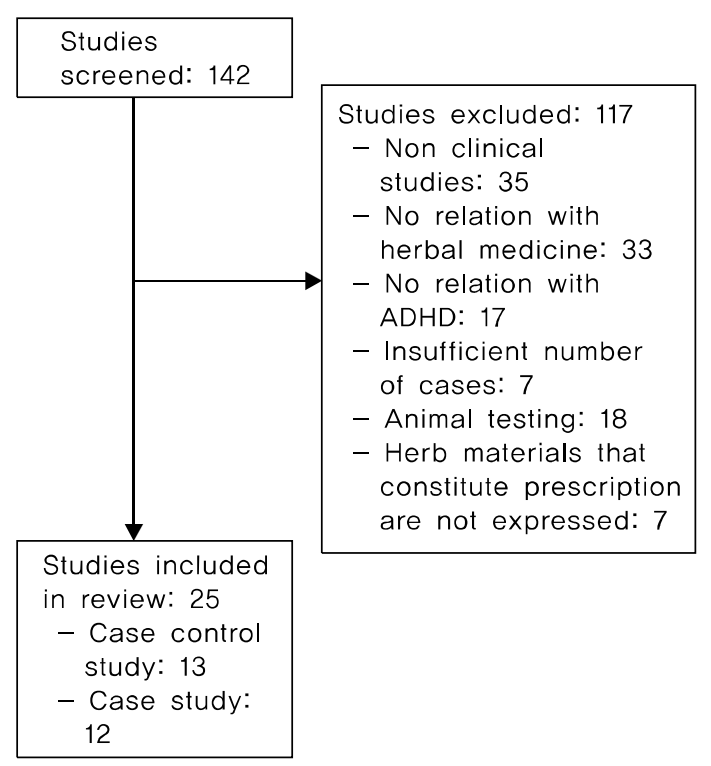

Fig. 1. Flow diagram preferred reporting items for review.

\section{III. 결과}

\section{1. 대상연구의 선정}

검색어를 통한 1 차 검색을 통하여 중복된 논문을 제외한 총 142 편이 검색되었다. 그 중 문헌적 고찰 등 비임상연구 논문 35편을 제외하고, 제목과 초록을 통 해 $\mathrm{ADHD}$ 와 관련 없는 논문 17 편, 동물 실험 18 편을 제외한 임상 논문 72 편을 선별하였다. 그 후 72 편 논문 의 전문을 분석하여 한약물이 주치료법이 아닌 논문 33 편, 증례가 1편인 논문(증례 3예를 단순 나열한 1편 포함) 7편, 구성약물의 기재 없이 처방 이름만 언급된 논문 7편을 제외한 후, 단일임상연구 12 편, 비교임상 연구 13편 등 총 25 편의 논문을 선정하였다(Fig. 1).

\section{2. 임상연구의 개요}

연구의 설계방법, 연구대상의 특징, 평가기준, 결 과 등을 정리하였다(Table 1,2 ).

\section{IV. 고찰}

\section{1. 연구의 설계}

모든 비교임상연구에서 선정기준, 제외기준은 제 시하였으나, 무작위 배정의 과정 및 맹검에 관련한 자세한 기술은 없었고, $\mathrm{Korng}^{24)}$ 의 연구에서만 탈락자 의 수와 이유에 대한 언급이 있었다. Jadad Quality Assessment Scale 점수는 모두 1점 이하로 논문의 질 은 낮은 편이었다. 하지만 국내 연구에 비해서 연구 의 규모나 수가 비교적 앞서 있기 때문에 임상적으로 참고할 가치가 있는 것으로 보인다.

\section{2. 진단기준}

진단기준으로는 DSM-IV를 사용한 논문이 11편으 로 가장 많았고, ICD-10, DSM-III를 사용한 논문이 각각 2편, 中国精神疾病分类与诊断标准(CCMD-3:3 편, CCMD-2R:1편)을 사용한 논문이 4편이었고, 나머 지에서는 임상증상에 의해 진단했다고 기재하거나 특별한 언급이 없었다.

\section{3. 평가기준}

치료효과 및 부작용 평가에서는 특별한 척도 없이 임상증상의 변화에 따라 평가한 경우가 13 편이었다. CRS (Conners Rating Scale)를 이용하여 평가한 논문 은 6편, CRS, IVA-CPT (Integrated Visual and Auditory Continuous Performance Test), 지능검사를 함 께 사용한 연구, CRS와 C-WISC (Chinese-Wechsler Intelligence for Children Scale)를 함께 사용한 연구, CRS, Cancellation test, Safety test (AST, ALT, Cr, $\mathrm{ECG}$ )를 함께 사용한 연구, CRS, Achenbach (Child Behavior Checklist-CBCL), CGI, TESS (Toxic Exposure Surveillance System)를 함께 사용한 연구, TESS, $\mathrm{C}$-WISC, CRS를 함께 사용한 연구, CRS와 Lab 검사를 한 연구가 각각 1편이었다. CRS (Conners Rating 
4 The Current State of Clinical Studies for Herbal Medicine of Attention Deficit Hyperactivity Disorder (ADHD)

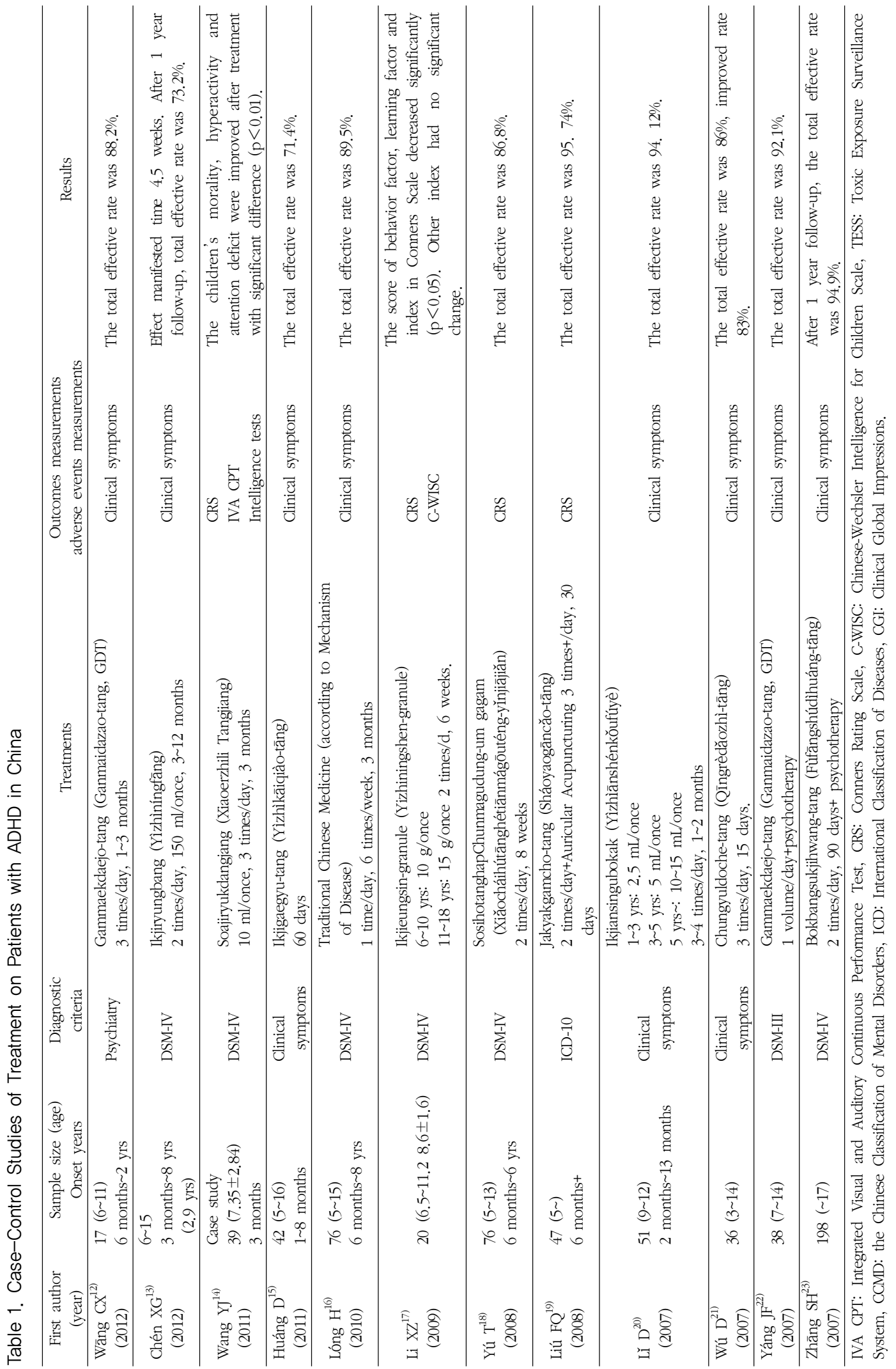


Scales)는 전 세계적으로 아동기 문제 행동 측정을 위해 가장 광범위하게 사용된 평가 도구들 중 하나로 볼 수 있으며, 또한 $\mathrm{ADHD}$ 아동을 대상으로 $\mathrm{ADHD}$ 증 상 및 이와 관련된 문제 행동들을 조사하기 위해 임상과 연구에서 널리 사용되고 있는 척도이다. CRS는 3 17세 사이의 아동을 대상으로 과잉행동과 기타 다른 문제 행 동들을 평가하기 위한 간편한 도구로써 부모용 평가 척 도와 교사용 평가 척도의 두 가지 형식으로 되어 있다 ${ }^{37}$. 객관적 척도를 사용하지 않은 논문이 절반이상으로 연 구 결과의 해석에 제한점을 가지며, 추후 국내 연구에서 는 이에 대한 고려가 필요하다고 하겠다.

\section{4. 치료결과}

단일임상연구는 총 12 편으로 변증에 따라 다른 처 방을 사용한 연구는 2편이었고(心肝陽方型/脾虛肝旺 型/腎虛肝光型-Lóng ${ }^{16)}$ ，滯熱內停，心火上炎/帶熱內 停, 引動肝風(-Wú $\left.{ }^{21)}\right)$, 다른 연구에서는 변증에 대해 언급하지 않았다. 한약물만을 치료에 사용한 연구가 9편, 耳鍼치료 결합 1 편, 심리치료 결합 2편이었고 Ritalin을 함께 사용한 경우는 없었다. 耳鍼治療를 함 께 시행한 연구 ${ }^{18)}$ 에서는 芶藥甘草湯과 腎, 心, 皮質 下, 神門, 枕 등의 耳穴에 王不留行을 붙여 자극하는 방법을 함께 사용하였다. 심리치료로는 Zhāng ${ }^{23)}$ 은 부모에 대한 심리지지와 아이를 교육하는 방법과 순 서를 교육하고, 의사가 아이의 상태를 평가하고 격려 및 심리 암시를 시행하였고, Yáng ${ }^{22)}$ 은 부모를 통해 아이의 자신감을 불어 넣어주고 존중하도록 하며, 병 을 치료할 수 있다는 믿음을 주어 자제력을 강화 시키 는 동시에, 부모와 선생은 아이의 작은 발전에도 격려 와 지지를 보내고 거친 행동을 기억하여 서로 공유하 도록 하였다. 인지기능을 함께 평가한 연구 ${ }^{16}$ 에서 인 지기능은 치료 전후의 큰 변화가 없었다. 12 편의 논 문에서 적어도 $71.4 \%$ 이상의 유효율을 나타냈다.

비교임상연구는 총 13 편으로 1 편을 제외한 나머지 12편에서 Ritalin 복용군을 대조군으로 설정하여 연구 를 진행했다. 나머지 한편에서는 전정기능 훈련을 위
주로 감각통합훈련을 시행한 집단을 대조군으로 설 정하였다. 변증이 언급된(또는 치법이 표기되어 변증 을 유추할 수 있는 경우) 연구는 7편(滋水涵木法$\mathrm{Qian}^{27)}$, 腎陰不足, 肝陽偏㐊-Wang ${ }^{28)}$, 腎陰不足,肝陽 偏旺/心脾氣虛，神失所養/濕熱內蘊，痰火擾心/瘀血 內阻, 腦絡失養-Lín ${ }^{30)}$, 腎虛肝旺-Zhèng ${ }^{32)}$, 㞷腎填精$\mathrm{MA}^{34)}$, 肝腎陰虛-Kǒng ${ }^{24)}$, 平肝熄風, 淸熱化疾-Shi ${ }^{36)}$ ) 이었다. 치료 수단으로 한약만을 사용한 연구가 7편, Ritalin을 함께 사용한 연구가 2편, 심리치료를 함께 시행한 연구 2 편, 감각통합훈련을 시행한 연구, 바이 오 피드백을 시행한 연구가 각각 1편이었다.

Zhāng ${ }^{31)}$ 은 한약물과 전정기능을 중심으로 한 감각 통합치료와 심리치료, 행동치료를 병행한 치료조와 감 각통합치료(60 100 $\mathrm{m}^{2}$ 의 공간 안에 스케이트보드, 미 끄럼틀, 드럼 등을 두고, 전문가의 지도하에 아동이 가볍고 즐겁게 참여하고 훈련하도록 유도하여 1 1.15 시간 시행)와 심리치료, 행동치료를 병행한 대조군으 로 시행한 연구를 통해 유의한 치료율의 차이와 빠른 치료효과를 얻었다고 보고했다. $\mathrm{Li}^{335)}$ 는 静灵口服液 복 용과 함께 바이오피드백을 시행한 치료군과 Ritalin과 바이오피드백을 함께 실시한 대조군으로 시행한 연구 를 통해 유의한 차이의 치료율과 낮은 재발율, 부작용 발생율의 결과를 보고했다. 이상의 치료 결과를 통해, $\mathrm{ADHD}$ 에 대한 한약물 치료가 유효함을 알 수 있었고, 이를 국내 임상연구에 응용할 수 있을 것으로 생각된 다. 다만, 앞서 연구의 설계에서 언급했듯이 논문의 질이 낮은 편이므로 이에 대한 고려가 필요할 것이다.

\section{5. 변증 및 관련 장부}

변증이 언급된 연구는 총 9편으로, 그 중 腎陰虛와 관련된 변증이 7편으로 가장 많았고, 心火, 痰 등으로 도 질환을 바라보았다. 장부로는 腎, 肝, 心 등과 관련 이 있는 것으로 보았다. 陰虛 변증이 많은 것은 소아 가 純陽之體인데다가 稚陰稚陽한 생리적 특징 때문 인 것으로 사료되며"), $\mathrm{ADHD}$ 환자를 치료함에 있어 서 陰虛 변증을 우선적으로 고려해 볼 수 있겠다. 


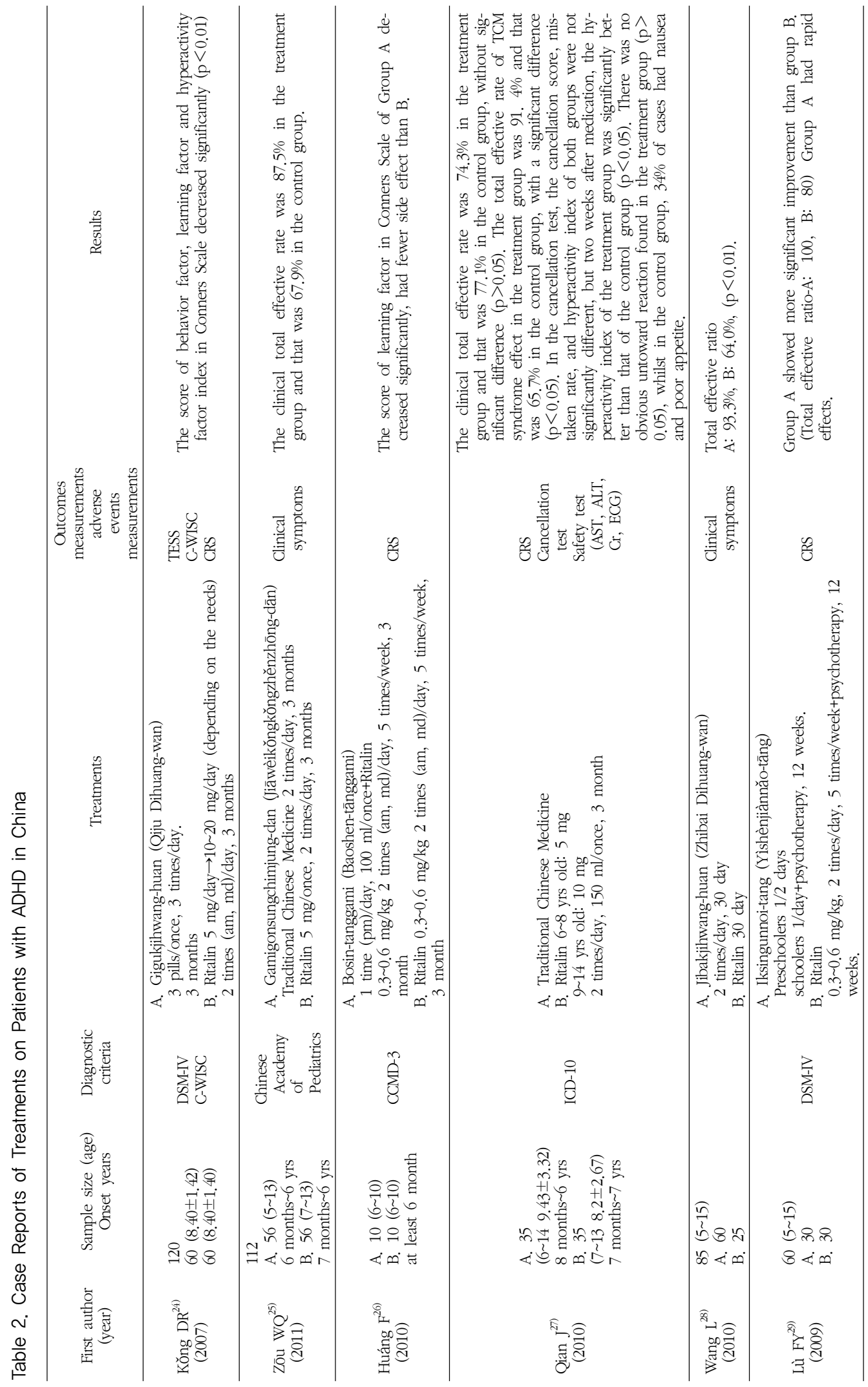




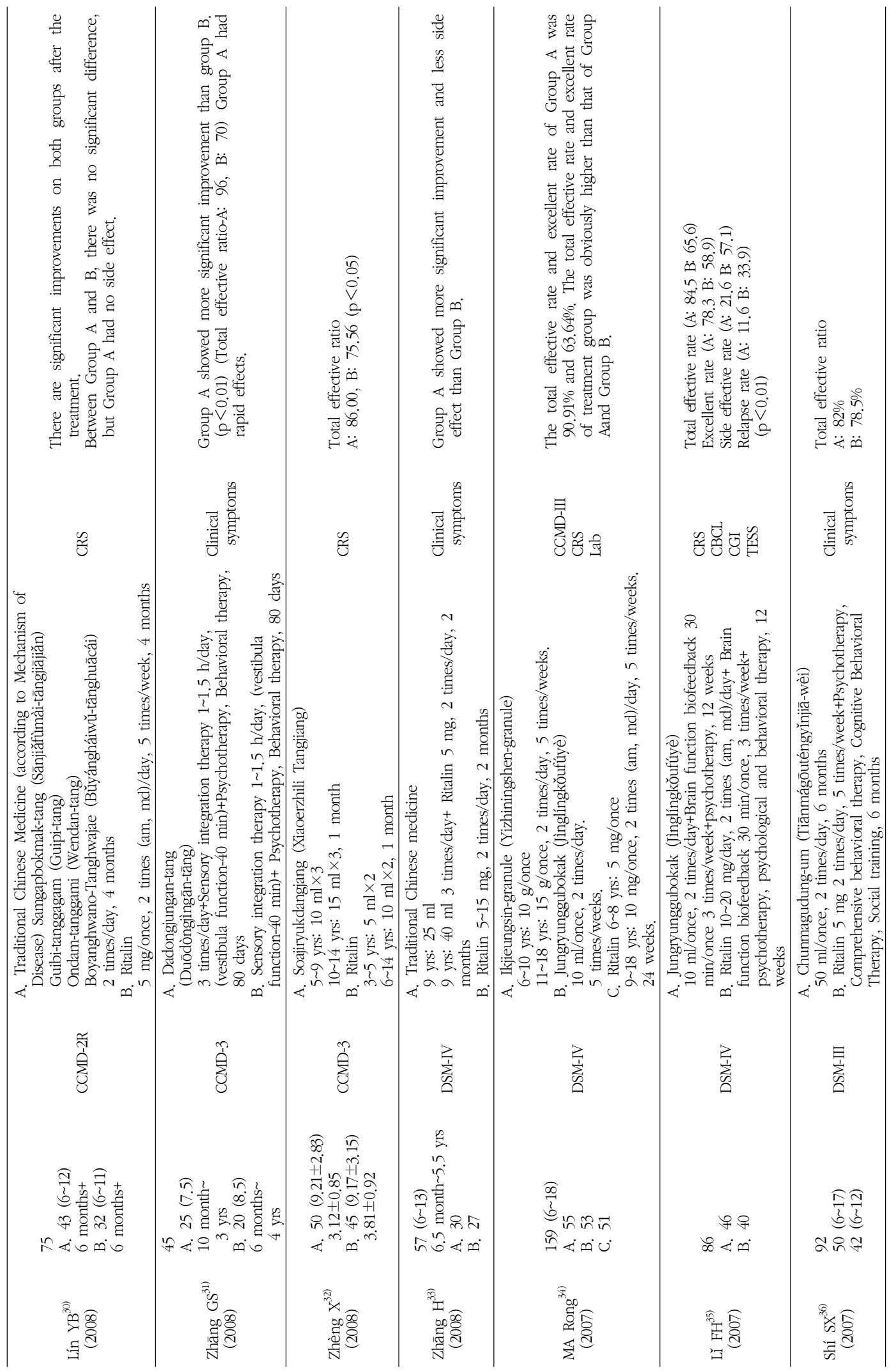


Table 3. Frequency of Herbal Materials that Constitute the Intervention Pre Scrptions

\begin{tabular}{cl}
\hline Frequency & \multicolumn{1}{c}{ Herbal materials } \\
\hline 16 & Rhizome of Polygalae Radix, Rhizome of Acori Gramineri Rhizoma \\
\hline 14 & Root of Glycyrrhiza uralensis Fisch \\
\hline 12 & Root of Rehmanniae Radix et Rhizoma Preparata, Sclerotium of Poria cocos Wolf \\
\hline 9 & Root of Paeonia japonica (Makino) Miyabe \& Takeda \\
\hline 7 & Sternum of Testudinis Plastrum \\
\hline 6 & $\begin{array}{l}\text { Seed of Ziyzyphus jujuba Miller, Root of Bupleuri Radix } \\
\text { gigas, Root of Rehmaniae Radix }\end{array}$ \\
\hline
\end{tabular}

\section{6. 사용된 한약물 분석}

25편의 논문에서 총 31개의 처방을 사용하였고, 증 상에 따라 가감한 약물을 제외한 94종의 약재가 사용 되었다. 熟地黃, 龜板, 鰵甲 등의 補陰劑와 遠志, 石菖 蒲, 获笭, 酸柬仁 등 心, 脾經에 작용하며 安神, 開竅 醒神하는 약물들의 빈도가 높았다. 그 중 遠志와 石 菖蒲가 16회로 가장 많이 사용되었다(Table 3). 遠志 는 心陽을 보조하고 痰濕을 ㅊㅎ하며, 心氣를 보익하여 腎氣로 하여금 상부의 心과 교통케 함으로써 交通心 腎, 安神益智의 효능이 있다. 그러므로 心腎不交로 나타나는 心腎不安, 驚悸, 失眠, 健忘 등을 치료한다. 石菖蒲는 淸陽의 氣를 振暢시키므로 醒神健腦하고, 和中開胃하므로 淸陽의 氣가 不升하여 나타나는 記 憶模糊, 癲狂, 痴呆 등 證에 상용된다. 甘草는 대부분 의 경우 佐使藥으로 쓰였고, 甘麥大東湯에서는 甘平 和中緩急하는 성질을 이용해 君藥으로 쓰였다. 熟地 黃은 補血, 滋潤시키며, 또한 生精盆髓시키는 효능이 있어서 肝, 腎二經을 補益시키는 要藥이 되어, 肝腎 不足과 心肝血虛 諸登에 사용한다. 获笭은 平甘淡하 여 心, 脾, 腎經에 작용하여 健脾寧心하며, 心神不安, 驚悸失眠 등의 證에 응용한다 ${ }^{38)}$. 상기 약물은 腎陰虛, 痰, 腎心과 관련된 변증이 많음에 따라 고빈도로 사용 된 것으로 보이며, 기존 처방에 가미하거나, 신약 개 발을 위한 실험 연구에 응용할 가치가 있는 것으로 생각된다.

\section{7. 부작용 분석}

한약물과 Ritalin을 함께 복용한 치료군과 Ritalin만 을 복용한 대조군과의 비교에서 $\mathrm{Huáng}^{25}$ 는 치료군 이 대조군에 비해 유의하게 낮은 부작용이 발생했음 을 보고했고, Zhāng ${ }^{32)}$ 는 치료군에서 식욕하강 7예 (23.3\%), 구건 3예(10.0\%), 오심 9예(30.0\%), 변비 6 예(20.0\%), 대조군에서 각각 26예(96.3\%), 14예 (51.9\%), 20예(74.1\%), 17예(63.0\%)로 유의한 차이 가 있음을 보고하였다.

Ritalin을 복용하지 않은 한약물 치료군과 Ritalin을 복용한 대조군과의 비교에서 $\mathrm{Qian}^{26)}$ 는 Safety test (AST, ALT, Cr, ECG)를 시행하여 대조군의 34\%에서 오심, 식욕저하가 발생하였고, 치료군에서는 부작용이 없었음을 보고하였다. $\mathrm{Lín}^{29)}$ 의 연구에서는 대조군에 서만 32예의 식욕저하, 17 예의 입면장애, 2 예의 두통 이 발생하였고, TESS를 이용한 $\mathrm{Li}^{34)}$ 의 연구에서는 치 료조 $21.6 \%$, 대조조 $57.1 \%$ 로 부작용 발생율의 유의한 차이가 나타났다. $\mathrm{Kǒng}^{24)}$ 의 TESS를 이용한 평가에서 도 치료조에서 유의하게 부작용 발생율이 낮았다.

결과적으로 한약물을 단독 복용했을 때뿐만 아니 라 한약물과 Ritain을 함께 복용한 경우에도 Ritalin 단독 투여시보다 부작용이 낮았다. 이를 통해 한약물 이 부작용이 적은 $\mathrm{ADHD}$ 의 치료방법일 뿐만 아니라, Ritalin과의 겸복을 통해 Ritain 부작용을 해결할 대안 이 될 수도 있을 것이라고 생각되며, 이에 대한 추가 적인 연구가 필요할 것으로 보인다. 


\section{V. 결론}

CNKI에서 제공하는 CAJ의 검색을 통해 2007년부 터 2012년까지 발표된 ADHD의 한약물 치료에 대한 최신 임상연구 동향을 분석해 다음과 같은 결론을 얻 었다.

1. 진단 기준으로는 DSM-IV를 사용한 연구가 11 편으로 가장 많았고, 치료 효과 평가 기준으로 는 임상증상의 호전에 따라 평가한 연구가 13 편, 척도로 $\mathrm{CRS}$ 를 사용한 경우가 12편이었다. 부작용 평가를 위해 TESS를 척도로 사용한 연 구는 2편이었다.

2. 변증 및 관련 장부는 腎陰虛와 관련된 변증이 가장 많았고, 장부로는 腎, 肝, 心등과 관련이 있는 것으로 보았다.

3. 빈용 한약물은 遠志, 石菖蒲 16회, 甘草 14 회, 熟地黃, 获笭 12 회, 苟藥 9회, 龜板 8회, 酸呆仁, 柴胡 7회였다. 처방의 선정이나 가감에 있어 상 기 약물을 우선적으로 고려해 볼 수 있을 것이 다.

4. 단일임상연구에서 유의하게 높은 효과를 나타 냈으며, 비교대조군 연구에서도 Ritalin 대조군 과 유사하거나 유의하게 높은 치료율을 보였다. 뿐만 아니라 부작용 발생율도 유의하게 낮으므 로 현재 치료목적으로 가장 많이 사용되는 Ritalin을 보완, 대체할 가능성이 있는 치료 방 법 중 하나임을 알 수 있었다.

\section{References}

1. Choi H, Kim JS, Lee EH. Clinical Study for Visual Application of Circle Pattern with 3G Color on Attention Deficit/Hyperactivity Disorder Patients. J Korean Oriental Med. 2010;31(1):47-56.

2. Choi MO. A Study on the Strengths Model-based Parenting Experience of the Children with ADHD. Korean Journal of Social Welfare. 2012;64(1):325-55.

3. Choi JA. Literature Review of Play Therapy
Intervention for Children with ADHD. Journal of the Korean Home Economics Association, 2012;50(5):125-38.

4. Kim JS, Kim BN, Cho SC, et al. The Side Effects and Correlates of OROS-Methylphenidate in the Treatment of Children and Adolescents with ADHD. J Kor Acad Child Adolesc Psychiatry. 2010;21(2):63-71.

5. Lee SG. A Study of the Children with Mental Disorders in Oriental Medicine. J of Oriental Neuropsychiatry. 2003;14(2):35-42.

6. Byun KW, Kim JH, Kim JW, Chung SY. Effects of Oriental Medical Treatment on ADHD - A Retrospective Clinical Survey -. J Korean Oriental Med. 2011;32(4):75-82.

7. Kim LH, Song BY, Yu G. 3 Case Reports of ADHD Childrem Treated with Acupuncture and Herbal Medicine. J of Oriental Neuropsychiatry. 2004; 15(1):239-46.

8. Kim HE, Kim JH. The Literature Study for Attention Defict Hyperactivity Disorder (ADHD) in Traditional Chinese Medical Journals. J Korean Oriental Pediatrics. 2006;20(2):59-75.

9. Lee TH, Kim LH, Jang IS, et al. A Review of Attention Defict Hyperactivity Disorder in Traditional Chinese Medical Journals. J of Oriental Neuropsychiatry. 2003;14(1):161-74.

10. Park HC, Kang MS, Kim LH. A review of Attention Defict Hyperactivity Disorder in Traditional Chinese Medical Journals. J of Oriental Neuropsychiatry. 2007;18(2):35-44.

11. Jadad AR, Moore RA, Carroll D, et al. Assessing the Quality of Reports of Randomized Clinical Trials: Is Blinding Necessary? Controlled Clinical Trials 1996;17(1):1-12.

12. Wāng CX. 17 Cases of Children with $\mathrm{ADHD}$ Treated by Gofanmaidazao-tang. Journal of Practical Traditional Chinese Medicine. 2012; 28(10):846.

13. Gāng XC, Tán LL, Xǔ SH, et al. Clinical Analysis about Treatment by Yìzhìníngfāng of Children with ADHD. Journal of New Chinese Medicine. 2012;44(7):104-5.

14. Wang YJ, Lu Y, Zheng Q, et al. Effect of the Xiaoerzhili Tangiiang to the Children of Attention 
Deficit/hyperactivity Disorder. Chin J Mod Drug Appl. 2011;5(18):4-5.

15. Huáng D, Tāng ZZ. 42 Cases of Children with ADHD Treated by Yìzhìkāiqiàotāng. Chinese Community Doctors. 2011;33:156-7.

16. Lóng $\mathrm{H}$. Traditional Chinese Medicine Treatment according to Mechanism of Disease of ADHD. Chin J Mod Drug Appl. 2010;4(6):127.

17. Ľ̀ XZ, Mă R, Ľ YP. Effect of Yizhiningshen Granule on Clinical Symptoms and Cognitive function of Children with Attention Deficit Hyperactivity Disorder. Journal of Tianjin University of Traditional Chinese Medicine. 2009;28(4): 178-9.

18. Yú T, Liú L. 76 Cases of Children with ADHD Treated by Xiăocháihútānghétiānmágōuténgy̌nnjiājiăn. TCM Res. 2008;21(4):40-1.

19. Liú FQ. 47 Cases of Children with ADHD Treated by Sháoyaogāncăotāng with Auricular Acupuncturing. Gansu Journal of TCM. 2008;21(7):33-4.

20. Lǐ D. 51 Cases of ADHD Treated by Yìzhiānnshénkǒufúyè. Strait Pharmaceutical Journal. 2007; 19(3):81-2.

21. Wú D. 36 Cases of Children with ADHD Treated by Qīngrèdăozhì-tāng. Chinese Journal for Clinicians. 2007;35(6):57.

22. Yáng JF. 38 Cases of Children with ADHD Treated by Ganmaidazao-tang with P2ychotherapy. Chinese Journal of GMTCM. 2007;22(5): $73-4$.

23. Zhāng SH. Chinese Medicine Treatment of 198 Cases of Children with ADHD. Journal of Traditional Chinese Medicine in Liáoníng. 2007; 34(5):600

24. Kǒng DR, Huò J, Fù HP, et al. 38 Cases of Children with ADHD Treated by Qiju Dihuang Wan. Shandong Journal of Traditional Chinese Medicine. 2007;7:445-7.

25. Zōu WQ. 56 Cases of Children with ADHD Treated by Jiāwèikǒngkǒngzhěnzhōngdān. TCM Res. 2011;24(6):47-8.

26. Huáng F. Clinical Observation of Integrative Medicine to Treat Children with Attention Deficit Hyperactivity Disorder. Medical Journal of Chinese People's Health. 2010;22(10):1265-6.
27. Qian J. Clinical Observation on the Effect of Nourishing the Liver and Kidney on Children with Attention Deficit Hyperactivity Disorder: A Report of 35 Cases. Journal of Traditional Chinese Medicine. 2010;51(1):37-40.

28. Wang L. ZhibaiDihuangPill Treating 60 Cases of ADD of Deficiency of Yin Leading to Hyperactivity of Yang Type. China Journal of Chinese medicine. 2010;25(147):324-5.

29. Lù FY, Mă FF, Féng SW. Clinical Observation of Integrative Medicine with Psychotherapy to Treat Children with Attention Deficit Hyperactivity Disorder. Modern Journal of Integrated Traditional Chinese and Western Medicine. 2009;18(29): $3357-8$.

30. Lín YB. Traditional Chinese Medicine Treatment according to Mechanism of Children with Attention Deficit Hyperactivity Disorder in 43 Cases. Fujian Journal of TCM 36 February. 2008;39(1):36-7.

31. Zhāng GS. Clinical Observation of Integrative Medicineto Treat Children with Attention Deficit Hyperactivity Disorder. Journal of Sichuan of Traditional Chinese Medicine. 2008;26(10):92-3.

32. Zhèng X, Zhū KJ, Liú TS, et al. 38 Cases of Children with ADHD Treated by Xiaoerzhili Tangjiang. Human Journal of Traditional Chinese medicine. 2008;24(5):33-4.

33. Zhāng H, Zhōu XF. 30 Cases of Integrative Medicineto Treat Children with Attention Deficit Hyperactivity Disorder. Journal of Practical Traditional Chinese Medicine. 2008;24(3):163.

34. MA Rong, Lǐ XM, Wèi XW, et al. Clinical Observation of Yishentianjing Method on Treating Fifty-five with Children Attention Deficit Hyper Activity Disorder. Journal of Tianjin University of Traditional Chinese Medicine. 2007;26(3):122-5.

35. Lǐ FH, Wáng YS, Yuán J. Clinical Observation of Jìnglíngkǒufúyè with Biofeedback to Treat Children with Attention Deficit Hyperactivity Disorder. Tianjin Journal of Traditional Chinese Medicine. 2007;24(4):268.

36. Shí SX. 50 Cases of Children with ADHD Treated by Tiānmágōuténgyy̌njiā̄è̀i. Traditional Chinese 
Medicine Information Magazine. 2007;14(10):69.

37. Conners CK. Conners' Rating Scales Manual. North Tonawanda, NY: Multi-Health Systems; 1989.
38. The Compilation Committee of Herbalogy. Herbology. 1st ed. Seoul: Younlimsa; 2004;535-6, 565-6, 586-8, 635-8, 348-350. 
